UDC 330.3(477)

JEL Classification: O11

Tkachenko A.M. ${ }^{a}$, Pozhuieva T.O. ${ }^{b}$

\title{
THE ALTERNATIVE RESOURCES OF ENERGY DEVELOPMENT IN SOLVING GLOBAL ECONOMIC PROBLEMS
}

\author{
${ }^{a}$ Zaporizhzhya National Technical University, Zaporizhzhya, Ukraine \\ ${ }^{b}$ Ukrainian State University of Chemical Technology, Dnipro, Ukraine
}

\begin{abstract}
The purpose of this article is to study the economic profit of Ukraine regarding the use of electric vehicles and the detection of health damage caused by the use of this type of transport. At present, the issue of the pathogenic impact of electric vehicles on the health of users, as well as the damage to them from the environment, has not been properly addressed. So now it's clear that the use of electric vehicles will reduce emissions to the atmosphere is probably not worth. In general, when considering the issue of reducing pollution in cities it is expedient to consider not only issues related to the use of electric vehicles, but also in general, as well as the likely consequences of this process. In general, this issue should be investigated in a complex manner together with technical specialists, considering that the receipt of electric energy is not always an environmental process by studying as a whole how this process affects the environment. We believe that in today's environment the issue of the expediency of widespread use of electric vehicles remains open. In order for the use of electric vehicles really to be as ecological as possible, it is first of all to receive energy from «clean» sources. In addition, it must be remembered that electric vehicles, like all electrical appliances, have a rather powerful electromagnetic radiation. There is currently no clear definition of what the direct effect of electromagnetic radiation is harmful to human health. In most countries, little attention is paid to the study of the strength of electromagnetic fields, therefore, scientists should consider this issue comprehensively and rather meticulously. At the same time, it is worth emphasizing that the future of electric vehicles and the fact that as a whole humanity will come to realize such a project depends on the quality of our lives.
\end{abstract}

Keywords: Alternative Energy Sources, petroleum, diesel, gas, economic profit, pollution.

DOI: $10.32434 / 2415-3974-2018-8-2-97-103$

\section{Introduction}

Now the world is constantly evolving and trying a switch to alternative energy sources. The reducing of consumption of natural resources and therefore to return to the stone age no one wants, so the only way is to search for alternative energy sources. By successfully implementing the emulation policy, we have achieved unprecedented technological heights for today. Realizing that it is impossible to continue to move through the intensive exploitation of natural and raw materials, because it is a large amount of emissions, and global warming, and related pathogenic mutations and natural disasters, we face the choice of what to do next? Of course to move forward we should lean previous experience, we shoud have to remember its advantages and bugs. In history, one of the most successful examples of the use of mechanics and power sources is the experience of
Leonardo da Vinci and Tesla. However, it is worthwhile to remember that Tesla's experiments had not only positive, but also negative effects in particular on weather-climatic processes of our planet. We need to be careful about the introduction of innovations and we have no right to use them thoughtlessly, especially if there is a threat to the environment. Given this, scientists and practitioners today need to consider the expediency and scale of the use of electric vehicles together.

The purpose of this article is to study the economic profit of Ukraine regarding the use of electric vehicles and the detection of health damage caused by the use of this type of transport.

At present, the issue of the pathogenic impact of electric vehicles on the health of users, as well as the damage to them from the environment, has not been properly addressed.

(C) Tkachenko A.M., Pozhuieva T.O., 2018 


\section{Main part}

Today in the big cities the emissions from cars are considered as the most threatening factor of the impact on the environment, because from year to year in Ukraine we observe tireless growth of volumes of fuel consumption (Figure).

As an alternative to reducing these emissions in recent years, consumers are offered the use of electric vehicles. But in our opinion, few people are concerned about the danger that electric vehicles produce. First of all, this is due to the disposal of batteries. $\mathrm{n}$ this regard, the systematic approach of Yuri Shevchuk [1] deserves attention to the rather interesting question: "How much will it cost to dispose of batteries from electric vehicles with the massive introduction of this type of transport, both on a global scale and on a countrywide scale? Especially, considering that such batteries work on average only $4-5$ years.» Shevchuk Yu came to the conclusion that expectations of electric vehicles as saviors of the environment at the present stage of development of science and technology are unconvincing because the batteries for modern electric vehicles are not only expensive, but also to a certain extent toxic. Lithium-ion batteries are usually used in electric vehicles, and the extraction of rareearth elements is now an urgent issue for the formation of a safe environment. The recycling of batteries from electric vehicles is a fairly costly process, which uses almost 10 times more energy to directly extract existing metals than is necessary to produce materials using an alternative method. In industrial processing, the proportion of cobalt, lithium, and other heavy metals, highly dispersed carbon, as well as the component of the electrolyte - LiPF6, having a carcinogenic effect, get directly into the atmosphere. Usually today the production of one electric vehicle is equated to 10 tons of conventional fuel is emitted during the burning process, so as much fuel consumes internal combustion engine in its entire life. Certainly there are no zero emissions from cars, because it is dust from abrasion of road surfaces and tires, as well as evaporation of oils and thermal pollution of the atmosphere.

Noteworthy are the calculations made by the
Research Institute of the Ministry of Transport of Ukraine, which show that every passenger car, before the wear of the tread of the tire, completely releases an average of over $14 \mathrm{~kg}$ of rubber dust, and a truck (with a 4CH2 wheel formula) of about $92 \mathrm{~kg}$. In addition, the intensity of ejection of dust from rubber in cars using tires rebuilt using the method of overlaying a new tread is 2 times greater than that produced in a serial way. According to the calculations of the Research Institute of the Ministry of Transport of Ukraine, trucks on average annually release about 30 tons of dust from the rubber into the environment, which contains rather harmful substances that accumulate in the atmosphere and soil: rubber, lubricants, resins and soot.

However, we should pay attention to two extremely expressive aspects:

1. In large cities, where the load of main (and somewhere and secondary) roads is too high, we can not only measure the level of emissions from vehicles by special equipment, but also feel it with the help of organs of smell. Ordinary citizens and employees, who are forced to stay in such places for a long time, note the high level of their pollution. And such an effect on small children is a catastrophe.

According to Treskov Yu.V. [2] motor transport in large cities creates a large area with a share of air pollution of $70-90 \%$, because the use of ICE produces a lot of noise and smoke, which is amplified through «traffic jams» on individual sections of roads. All this resulted in the emergence of electric vehicles.

2 . If you prefer electric cars, then do not forget about the electromagnetic radiation [10] they create, which is extremely dangerous especially for pregnant women and pets.

Some scientists say that the use of electric cars will reduce emissions and provide data on urban pollution, while others say that because of the fact that receiving electricity is not an environmental process, then on the contrary, we will further pollute our planet.

So, now the question of the expediency of widespread use of electric vehicles remains open. However, this process is alarming at the position of some of the leading countries that are suppliers of fuel and lubricants. Thus, according to the

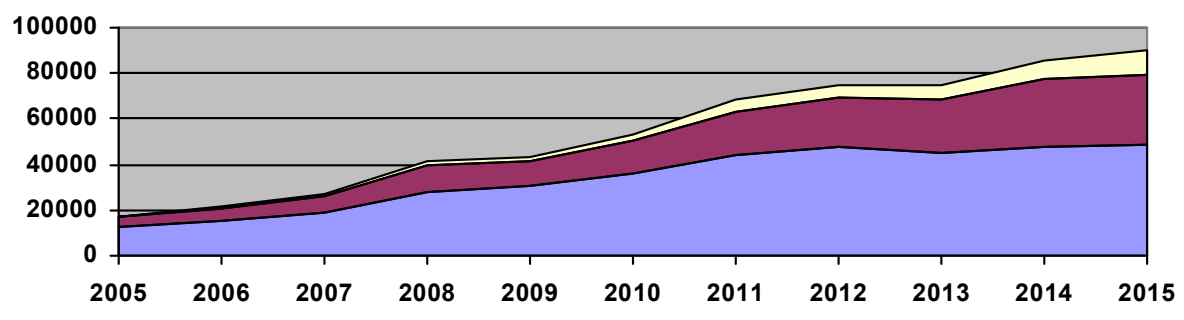

$\square$ petrol engine $\square$ diesel fuel $\square$ gas compressed and liquefied 
Presidential Decree (of the Russian Federation): «The main challenges and threats to economic security include:» ... 6) the change in the structure of global demand for energy resources and their consumption patterns, the development of energy saving technologies and the reduction of material resources, the development of «green technologies» ...» [4]. But the main thing - electric cars (so far) are working on the same energy from burnt fossil fuels as the car with an internal combustion engine. Just fuels coal, oil, gas - are burnt in thermal power plants and through electrical wires, with heavy losses, greatly increasing the price of energy goes to electric. In order for electric vehicles to really become «clean», they must receive energy from «clean» sources [1]. Currently, some countries such as China, Canada, Japan - began to produce «flammable ice» - a hydrate of natural gas. One cubic meter of natural gas hydrate equals 160 cubic meters of natural gas in a gaseous state. For comparison: 100 liters of «fuel ice» car can travel 50 thousand kilometers [6]. Today, the cost of one kilometer of the road is about one $\mathrm{UAH}$, that is, $100 \mathrm{UAH}$. / $100 \mathrm{~km}$, or approximately 2.4 liters of diesel fuel (in Ukraine the liter of diesel fuel is approximately equal to the cost of USD 1) [7]. If the use of hydrate of natural gas will be introduced, this will allow in the ecological sense to make electric cars really «clean», and in such conditions the problem of frequent recharging and difficulty of operation in the winter period in Ukraine, along with affordability and low cost, will be solved [5].

Electric cars, like all electrical appliances, have electromagnetic radiation. Kukharov AM and Evdokimov MV [8, p. 92] note that the vehicle, although it is a relatively low-power source of electromagnetic radiation (EMR), but the problem of EMR exists. At the same time, there is still no clear definition of what level of exposure is harmful to health, since official safety tests in most countries do not measure the strength of such fields in cars. The nature of electromagnetic radiation is associated with vortex electrical and magnetic fields, the degree of influence is determined by the amount of energy of electromagnetic radiation, depending on the frequency or wavelength. By electrical properties, most living tissues at frequencies above $60 \mathrm{kHz}$ can be considered as anomalous dielectrics. In turn, Kukharev AM and Evdokimov MV successfully noted that during the operation of the level of electromagnetic radiation in particular from the system of ignition of the car due to aging processes of various structures and elements that affect the parameters of the electromagnetic field increases [8, c. 92]. With reference to Kirichenko VI [9], the same authors emphasize that the nature of the EMR in an electric vehicle is much more complicated than in a car equipped with an internal combustion engine.
Thus, electric vehicles have a direct harmful effect on the human body.

Objective data for analyzing the radiation level of an electric vehicle has not been made public today, and some data relate only to enthusiasts who at their own expense took measurements of this radiation and, of course, their results do not coincide with the «official» data of automakers.

We will select in Ukraine the most popular models of cars and compare their harmful effects on the human body with the corresponding data of electric vehicles (tab.). [5,7,8,9,14].

Certainly not enough information now made public in order to draw a conclusion about the harmful influence on the human right vehicle equipped with an internal combustion engine or electric. Worthy of note are the results of a study by a British scientist from the University of Hertfordshire Rangit Soha who in 2013 conducted such an experiment: in the automobile tunnel, through which an average of about 50 thousand cars passes over the course of the day, detectors of solid particles were installed. According to the data obtained, each car produced about 30-50 micrograms of solid particles, of which only about one-third were engine emissions. Most of the harmful substances were tires of wheel tires, bitumen road surfaces and dust from the braking system. Consequently, exhaust gases in the operation of motor vehicles are not the greatest danger to the modern environment [3].

According to the results of modern scientists, $\mathrm{CO}_{2}$ emissions (in grams per $\mathrm{kWh}$ produced) were significant both for gasoline cars and for electric vehicles. It was established that after the release of suspended particles the «dirtiest» ones are diesel cars in the second place were electric cars, and the third was occupied by gasoline.

Specialists from ADAC (Allgemeiner Deutscher Automobil-Club) have estimated that even a compact Smart class electric car that is powered by coal-fired power supplies (indirectly) emits 107 grams of carbon dioxide per kilometer, which is 21 grams more than Smart on a conventional diesel fuel [1].

Of course, the question arises whether dangerous cars with an internal combustion engine are so dangerous and do European environmentalists not exaggerate the harm they produce for the environment?

The use of electric cars will not help reduce petroleum use. Despite the fact that the electric car does not directly burn diesel or gasoline, but the direct production of electricity burns the same oil. It is also worth taking into account the loss of energy that occurs when it is transported. In general, the profit from such supposedly no savings. That is, the emissions to the environment will be not from cars, but from large power plants. But in general, the amount of these emissions will not decrease. 
The harmful effects on the environment of different modes of transport

\begin{tabular}{|c|c|c|c|c|c|c|c|}
\hline 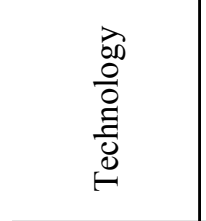 & $\begin{array}{l}\text { Most popular } \\
\text { models in } \\
\text { Ukraine, their } \\
\text { distribution } \\
\text { coefficient** }\end{array}$ & $\begin{array}{l}\text { Source } \\
\text { power } \\
\text { supply }\end{array}$ & $\mid \begin{array}{c}\mathrm{CO}_{2} \text { content } \\
\text { in the source } \\
\text { fuel } \\
\mathrm{g} / \mathrm{MJ}\end{array}$ & $\begin{array}{c}\text { Full } \\
\text { energy } \\
\text { efficiency } \\
\mathrm{km} / \mathrm{MJ}\end{array}$ & $\begin{array}{c}\text { Environmental } \\
\text { efficiency } \\
\left(\mathrm{CO}_{2}, \mathrm{~g} / \mathrm{KM}\right)\end{array}$ & $\begin{array}{c}\text { Electromagnetic } \\
\text { radiation, } \\
\text { average per } \\
\text { group* }\end{array}$ & Disadvantages \\
\hline 1 & 2 & 3 & 4 & 5 & 6 & 7 & 8 \\
\hline $\begin{array}{c}\text { Engine on } \\
\text { natural fuel }\end{array}$ & Honda CNG & $\begin{array}{c}\text { Natural } \\
\text { gas }\end{array}$ & 14,4 & 0,32 & 45,0 & & \\
\hline $\begin{array}{l}\text { Hydrogen } \\
\text { fuel cells }\end{array}$ & Honda FCX & $\begin{array}{c}\text { Natural } \\
\text { gas }\end{array}$ & 14,4 & 0,35 & 41,1 & & \\
\hline $\begin{array}{l}\text { Diesel } \\
\text { engine }\end{array}$ & RENAULT 4\% & petroleum & 19,9 & 0,48 & 41,5 & \begin{tabular}{|c|} 
intensity of \\
electromagnetic \\
radiation- \\
$28-32 \mathrm{~dB}$ \\
at 1 unit \\
\end{tabular} & \\
\hline 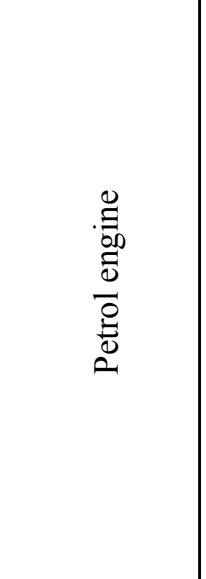 & 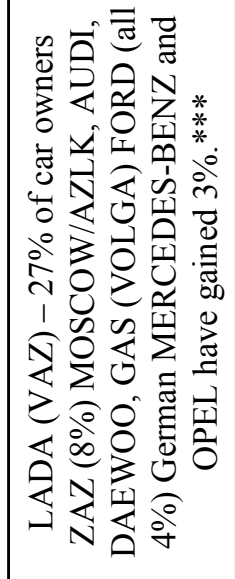 & petroleum & 19,9 & 0,48 & 41,5 & $\begin{array}{c}\text { The field } \\
\text { strength of the } \\
\text { petrol engine is } \\
40-60 \mathrm{~dB}\end{array}$ & \\
\hline 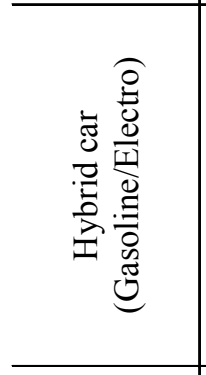 & Toyota Prius & petroleum & 19,9 & 0,64 & 31,1 & $\begin{array}{l}30-170 \\
\text { millihauss, } \\
\text { which is } \\
15-135 \text { times } \\
\text { higher than } \\
\text { normal }\end{array}$ & $\begin{array}{c}\text { They have a much } \\
\text { higher background o } \\
\text { electromagnetic } \\
\text { radiation than } \\
\text { normal, and } \\
\text { especially in the are } \\
\text { of the rear seats, } \\
\text { which usually sit } \\
\text { children } \\
\end{array}$ \\
\hline $\begin{array}{c}\text { Electro, } \\
\text { according to } \\
\text { the } \\
\text { automobile } \\
\text { manufacturer }\end{array}$ & Tesla Roadster & $\begin{array}{c}\text { Natural } \\
\text { gas }\end{array}$ & 14,4 & 1,14 & 12,6 & $\begin{array}{l}\text { No data } \\
\text { available }\end{array}$ & $\begin{array}{l}\text { Electric car in the } \\
\text { winter will be } \\
\text { discharged, the } \\
\text { capacity of the } \\
\text { batteries will fall. } \\
\text { He needs regular } \\
\text { maintenance and } \\
\text { maintenance }\end{array}$ \\
\hline
\end{tabular}


The alternative resources of energy development in solving global economic problems

The harmful effects on the environment of different modes of transport

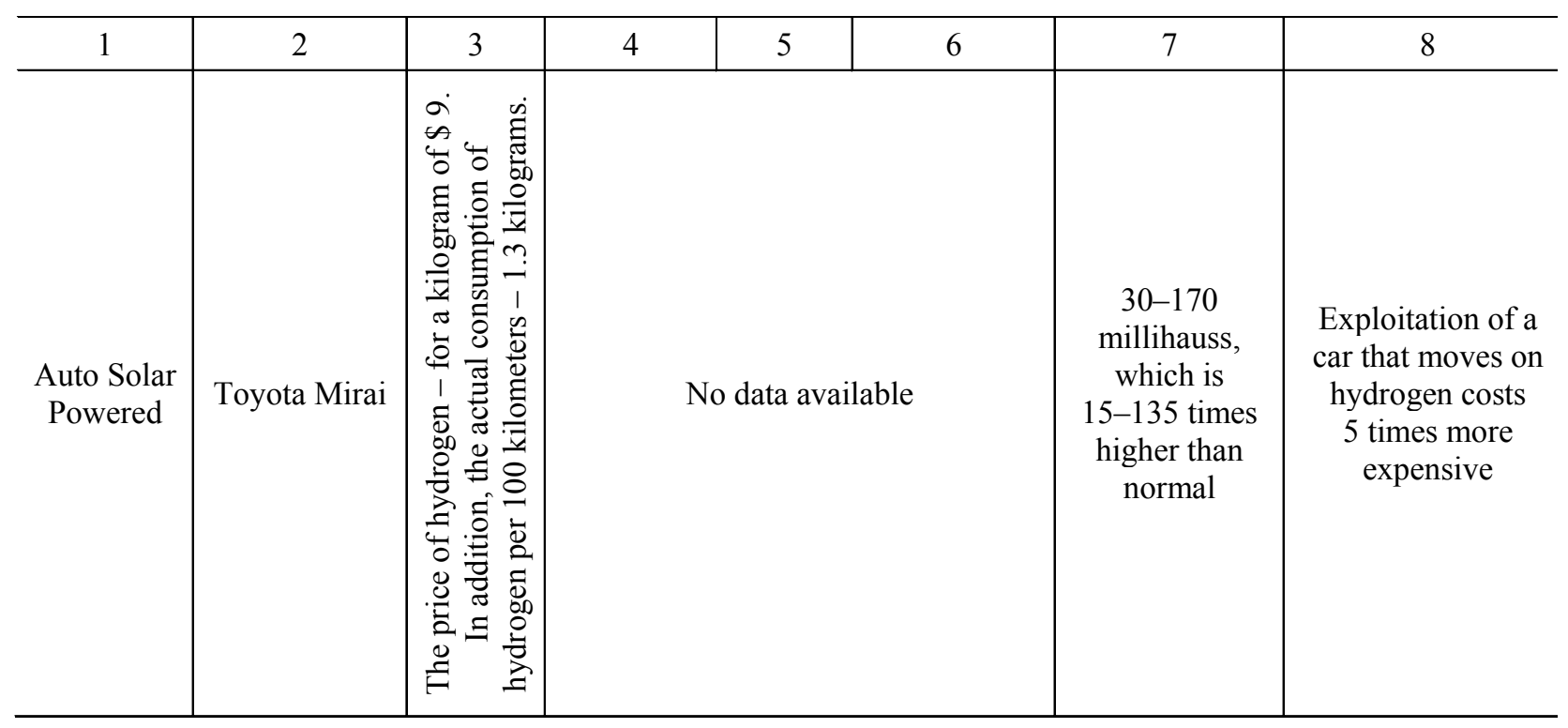

Note: * - for the average in the group of electrons radiation was taken that corresponds to the average age of motor vehicles operated on the Ukrainian roads; ** - coefficient of distribution - distribution of this type of transport in the country, interest. According to objective data, we consider the percentages, since we can measure how much each type of transport is used on average for one year, therefore, another column is added corresponding to the total consumption of motor vehicles of a particular type of energy and correlates the calculations of harmful influence according to this data; *** - the amount of gas processed for gas is not taken into account; *** - the data are given without taking into account the temporarily occupied territory of the Autonomous Republic of Crimea and the city of Sevastopol and part of the ATO zone.

Traditionally, it is believed that in large cities cars are the main polluters of the environment, at least about $80 \%$. But this information is quite exaggerated. First, the emissions from household sources - in particular, household gas cookers, which generate emissions of more than $20 \%$ of carbon monoxide and about $3 \%$ of nitrogen oxides. Secondly, the emissions from so-called «biological sources»humans, animals, trees, which also allocate with pleasure large volumes (at breath) carbon dioxide, considerably more than are absorbed directly at photosynthesis, are not taken into account. Thirdly, society for some reason forgets that it is currently responsible only for $25 \%$ of pollutants that enter the atmosphere, while $75 \%$ are generated by natural impacts, including direct volcanic eruptions, dust storms, forest fires, dust of cosmic origin, and so on.

In general, it is appropriate to take into account all existing pollution, and not only anthropogenic. The person does not care why it is difficult for him to breathe either through cars behind the windows, or because of forest fires that take place many kilometers from his home. But, is it likely that the use of innovative renewable energy technologies will be a direct way out of such a difficult situation?

According to forecasts by the agency Bloomberg New Energy Finance it should be emphasized that the share of renewable energy resources is increasing. In addition, renewable energy, including hydropower facilities, directly contributes to the growth of world electricity production from $12.6 \%$ in 2010 to $15.7 \%$ in 2030. From «pure» sources, the maximum that mankind can receive is $25 \%$ of its needs. Undoubtedly, humanity's energy needs are constantly growing. If the number of humanity for some reason (or its urgent need for resources) will decrease somewhere about 4 times, and humanity will only be able to receive «pure» energy only then the electric vehicles will cease to contaminate the environment and then only indirectly. And now it's unrealistic.

\section{Conclusions}

So now it's clear that the use of electric vehicles will reduce emissions to the atmosphere is probably not worth. In general, when considering the issue of reducing pollution in cities it is expedient to consider not only issues related to the use of electric vehicles, but also in general, as well as the likely consequences of this process. In general, this issue should be investigated in a complex manner together with technical specialists, considering that the receipt of electric energy is not always an environmental process by studying as a whole how this process affects the environment. We believe that in today's environment the issue of the expediency of widespread use of electric vehicles remains open. In order for the use of electric vehicles really to be as ecological as possible, it is first of all to receive energy from «clean» sources. In addition, it must be remembered that 
electric vehicles, like all electrical appliances, have a rather powerful electromagnetic radiation. There is currently no clear definition of what the direct effect of electromagnetic radiation is harmful to human health. In most countries, little attention is paid to the study of the strength of electromagnetic fields, therefore, scientists should consider this issue comprehensively and rather meticulously. At the same time, it is worth emphasizing that the future of electric vehicles and the fact that as a whole humanity will come to realize such a project depends on the quality of our lives.

\section{REFERENCES}

1. Шевчук Ю.Электромобили: польза или вред? / Юрий Шевиук // Syasnews. Електронний ресурс. - Режим доступу: http://syasnews.ru/raznoe/12115-elektromobili-polza-ili-vred

2. Трескова Ю. В. Электромобили и экология. Перспективы использования электромобилей // Молодой ученый. - 2016. - №12. - С. 563-565.

3. Міністерство інфраструктури України Електронний pecypc. - Режим доступу: https://mtu.gov.ua/content/ statistichni-dani-po-galuzi-avtomobilnogotransportu.html?PrintVersion

4. Указ Президента Российской Федерации «О стратегии экономической безопасности Российской федерации на период до 2030 года» от 13.05.2017 № 208 - http:// www.kremlin.ru/acts/bank/41921

5. Стало известно, сколько проезжает электромобиль Nissan Leaf зимой в Украине // Экономический известия http://news.eizvestia.com/news-auto/full/477-stalo-izvestnoskolko-proezzhaet-elektromobil-zimoj-v-ukraine

7. Михаил Брониславович. Путешествие на электромобиле Nissan LEAF по Украине. Электрокар и дорога // Elmob https://elmob.ua/news/puteshestvie-na-elektromobilenissan-leaf-po-ukraine-elektrokar-i-doroga/

8. Кухарев А.М., Евдокимов М.В. Автотранспортное средство как источник электромагнитной опасности // Технико-технологические проблемы сервиса. - №2(28). - 2014. - C. $91-94$

9. Кириченко В.И. Результаты исследования радиопомех, создаваемых автотранспортом. Текст. / В.И. Кириченко // Проблемы ЭМС РЭС различного назначения: 2-е Всесоюз. науч.-техн. совещание. НТОРЭС им. А.С. Попова, 1978. - C. 61

10. Effects of Cell Phone Radiofrequency Signal Exposure on Brain Glucose Metabolism / Nora D. Volkow; Dardo Tomasi; Gene-Jack Wang; et al // http://jamanetwork.com/ journals/jama/fullarticle/645813
11. Споживання бензину в Україні за три роки скоротилося на 40\% // Українські національні новини: Інформаційне агентство. Електронний ресурс - Режим доступу: http:/ /www.unn.com.ua/uk/news/1584922-spozhivannya-benzinu-vukrayini-za-tri-roki-skorotilosya-na-40

12. Роздрібна торгівля України у 2015 році. Статистичний збірник. / Державна служба статистики України. Київ, 2016. - 135 с. - С. 26. Електронний варіант: Статистика оптової й роздрібної торгівлі http://www.ukrstat.gov.ua/ druk/publicat/Arhiv_u/12/Arch_rt_zb.htm

13. Аналіз продажу пального в Україні у 2005-2013 роках // Infolight - інформаційно-аналітичний центр. Електронний ресурс - Режим доступу: http://infolight.org.ua/ content/analiz-prodazhu-palnogo-v-ukrayini-2005-2013-rokah

14. Державна служба статистики України. Електронний ресурс. - Режим доступу: http://www.ukrstat.gov.ua

Received 24.10.2018

Reviewer: prof. Kolesnikov V.P.

\section{АЛЬТЕРНАТИВНІ ДЖЕРЕЛА ЕНЕРГЕТИЧНОГО РОЗВИТКУ У ВИРІШЕННІ ГЛОБАЛЬНИХ ЕКОНОМІЧНИХ ПРОБЛЕМ}

\section{Ткаченко А.М., Пожуєва Т.О.}

Метою даної статті є вивчення економічного прибутку України щодо використання електричних транспортних засобів та виявлення шкоди здоров 'ю, заподіяної використанням иього виду транспорту. В даний час питання щодо патогенного виливу електричних транспортних засобів на здоров'я споживачів та зашкодження навколишньому середовишу не розглядаються належним чином. Загалом, розглядаючи питання зменшення забруднення у містах, доцільно розглянути не тільки питання, пов'язані з використанням електричних транспортних засобів, а й загалом, а також можливі наслідки цього процесу. Загалом, це питання слід досліджувати разом з технічними фахівиями, вважаючи, що отримання електричної енергї̈ не завжди є екологічним процесом, вивчаючи в цілому, як цей процес впливає на навколишнє середовище. Ми вважсаємо, що в сучасних умовах питання про доцільність широкого використання електричних транспортних засобів залишається відкритим. Для того, щоб використання електричних транспортних засобів насправді було максимально екологічним, слід користуватися енергією 3 «чистих» джерел. Крім того, слід пам'ятати, що електромобілі, як і всі електроприлади, мають досить потужне електромагнітне випромінювання. В даний час немає чіткого визначення того, який прямий ефект електромагнітного випромінювання шкідливий для здоров'я людини. У більшості країн мало уваги приділяється вивченню сили електромагнітних полів, тому вчені повинні розглянути це питання всебічно і досить ретельно. У той же час варто підкреслити, що майбутнє електромобілів і той факт, що в цілому людство прийде реалізувати такий проект, залежить від якості нашого життя.

Ключові слова: альтернативні джерела енергії, нафта, дизельне паливо, газ, економічний прибуток, забруднення. 


\section{АЛЬТЕРНАТИВНЫЕ ИСТОЧНИКИ \\ ЭНЕРГЕТИЧЕСКОГО РАЗВИТИЯ В РЕШЕНИИ ГЛОБАЛЬНЫХ ЭКОНОМИЧЕСКИХ ПРОБЛЕМ}

\section{Ткаченко А.М., Пожуева Т.А.}

Целью данной статьи является изучение экономической прибыли Украины по использованию электрических транспортных средств и выявления вреда здоровью, причиненного использованием этого вида транспорта. В настоящее время вопрос о патогенного воздействия электрических транспортных средств на здоровье потребителей и зашкодження окружающей среде не рассматриваются должным образом. В общем, рассматривая вопрос уменьшения загрязнения в городах, целесообразно рассмотреть не только вопросы, связанные с использованием электрических транспортных средств, но и в иелом, а также возможные последствия этого процесса. В общем, этот вопрос следует исследовать вместе с техническими специалистами, считая, что получение электрической энергии не всегда экологическим процессом, изучая в целом, как этот процесс влияет на окружаюшую среду. Мы считаем, что в современных условиях вопрос о иелесообразности широкого использования электрических транспортных средств остается открытым. Для того, чтобы использование электрических транспортных средств самом деле было максимально экологичным, следует пользоваться энергией из «чистых» источников. Кроме того, следует помнить, что электромобили, как и все электроприборы, имеют достаточно мощное электромагнитное излучение. В настоящее время нет четкого определения того, какой прямой эффект электромагнитного излучения вреден для здоровья человека. В большинстве стран мало внимания уделяется изучению силы электромагнитных полей, поэтому ученые должны рассмотреть этот вопрос всесторонне и очень тщательно. В то же время следует подчеркнуть, что будущее электромобилей и тот факт, что в целом человечество придет реализовать такой проект, зависит от качества нашей жсизни.

Ключевые слова: альтернативные источники энергии, нефть, дизельное топливо, газ, экономическая прибыль, загрязнение. 